\title{
RAPID PROTOTYPING POLITICS: DESIGN AND THE DE-MATERIAL TURN
}

Matthew Ward

\section{Introduction: The De-Material Turn}

Over the last two decades, design as a discipline has focused less on the production and manufacture of material things and become more concerned with immaterial or ephemeral interactions. The role of the designer has been rigorously debated and questioned, in part due to the rise of specialisms such as Interaction Design, User Experience Design, and Service Design (Press and Cooper 2003; Danish Designers Manifesto 2010; Inns 2010). Coinciding with this de-material turn in design practice, we have seen a 'material and speculative turn' throughout the humanities, whereby power and political agency are attributes of non-human entities - conjuring a world, in Jane Bennett's words, of 'vibrant matter' (Bennett 2010).

The 'material turn' has been expanded through different disciplines, from philosophy (Bryant, Srnicek, and Harman 2011) and cultural studies (Bennett and Joyce 2013) to anthropology (Hicks 2010), and reaffirms an examination of the material domain as essential for our understanding of current political and economic realities. This 'turn' moves us beyond a conceptualisation of the world as socially or technologically deterministic, towards a networked distribution of agency.

A world of distributive agency, where material entities are recognised actors that 'make the difference' and 'make things happen' (Bennett 2010: 9), naturally calls into question the role of design. Moving design from a politics of production to a production of politics calls for a radical rethink of the educational modes and frameworks built over the last century. This chapter examines the role of design in shaping, prototyping, and manipulating the political terrain and considers how educators might equip the next generation of designers with the appropriate ethos, mindset, tools, and techniques to survive and flourish in this new complex context.

In order to build a clearer picture of what I mean by the de-material turn, I look to design thinking as an exemplar of a sub-discipline that evolved without a material basis. With its history in the design science movement of the 1970s (Cross 2001) and its more recent adoption into innovation and business studies (Kimbell 2011), design thinking has been developed and deployed as a series of tools and methods outside the traditional mediums of design:

[Design thinking as] a discipline that uses the designer's sensibility and methods to match people's needs with what is technologically feasible and what a viable business strategy can convert into customer value and market opportunity. (Brown 2008) 
Design has always been held to account by, and tied to, market dynamics. Design thinking offers the logical conclusion to the free-marketisation of design practice. Devoid of the messy material complexities of production and free from the risk of creative misdirection, design thinking offers design as thought in and of itself. The de-material turn is the culmination of a gradual move towards the abstraction and professionalisation of design practice, eroding its material base towards a fully commodifiable non-thing. Design thinking could be considered as design in its purest form, where the process and method of creativity can be communicated, taught, and sold through snappy workshops with senior executives. As long as we throw enough coffee and Post-it notes at the problem, we will be able to harness the power of design to solve all business or social needs.

So while novel sub-disciplines or specialisms such as Service Design, Policy Design, Strategic Design, or Design Thinking get traction in boardrooms and think tanks across the globe, we run the risk of reducing our practice to a series of empty, market-focused thought experiments. It is not my intention to argue for an educational shift away from material learning, where business strategy or public policy offer new directions for design practice in the twenty-first century (I would say this is already happening). I would like to call for a closer interrogation of a new materiality for the post-disciplinary design generation. I aim to find the tangible 'matter', which might be manipulated through the prototyping and production of action, in order to allow design education to move into new and uncharted territories.

\section{The Decline of Material Learning in Design Education}

Within UK higher education, we have seen a decline in material learning in art and design. Computer-Aided Design (CAD) has become the dominant form of drawing, modelling, and making, and the computing lab has slowly replaced the dirty, resource-intensive workshop. In November 2014 the controversy surrounding the increasingly 'hands-off' nature of design education hit the design and craft press (Crafts Council 2014; Dezeen 2014). Petitions were signed, manifestos were written, and notable designers spoke up. Many were concerned that a reduction in workshop-based teaching would jeopardise the future of the creative industries, eradicating the playful exploration and sensitive understanding of our material domain.

A decline in material learning could simply be seen as reflecting the general shift in cultural production. As screen-based activities occupy more of our social and working lives, and as industrial production moves East, it is no surprise that the significance of material learning has diminished. However, in recent years the general public have become increasingly interested in materials and the 'made'. Whether this is in response to progressively de-materialised cultural production, a nostalgia for 'simpler times', or a reaction against the devaluation of manual 
activities by dominant ideologies, the resurgence of popular interest in the material domain actively contradicts trends in design education.

The history of British art and design education is a complex web of politics, funding policy, industrial evolution, and ego-driven intellectualism. From the postwar desire to educate the masses, to the strict specialisation and professionalisation of design in order to defend its purpose and value (evidenced by the 1970 Coldstream Report), we have arrived in the twenty-first century with a mix of specialisms that often fail to represent either the realities of industry or the intellectual context of knowledge production. Across many UK institutions, academics have set out to convince the world that design is serious, thoughtful, and ripe with intellectual opportunity, and consequently design education is largely moving away from the material tools of its history. Yet design educators have somewhat forgotten their unique position within the academy. We make things, to make sense of the world. Designers materialise thought in order to push the boundaries of knowledge. By taking a leap into the material abyss, we may risk ridicule and failure, but the capacity to bridge the object/thing divide (Bennett 2010:13) is what makes our practice invaluable.

\section{Towards a Post-Disciplinary Design Education}

Designers, like artists and crafts practitioners, have always understood the importance and 'power' of the material realm. Whether through the manual manipulation of raw materials or the planning and implementation of networks of production, the power to mould and transform social reality is a consistent drive within any creative endeavour. As the humanities have opened up new methods for interrogating society, affording insights into the heterogeneous assemblages of our socio-technical world, artists and designers have devised ever more sophisticated ways to imagine and produce the future.

Traditionally, design education is organised into specialist domains, linked to materials, tools, or industries. These silos emerged through a model of education that has its roots in the medieval guilds of craft artisans in the thirteenth and fourteenth centuries (Souleles 2013) and led to the control of tools and machinery for commercial exploitation. However, our tools have evolved, and digital networks increasingly allow for knowledge to be shared in ways that fracture established hierarchies. The model of education must therefore shift, in order to reflect and capitalise upon these new relationships, a model that moves away from the strict specialisms of the twentieth century towards a post-disciplinary future.

As the skills and working practices of designers are increasingly deployed across a range of atypical organisations (for example, the National Health Service, governments, venture capital firms), we can imagine design transforming itself 
towards an interdisciplinary space of production. This space of production constitutes an emerging territory, one in which we do not yet know the precise role or function of design as it has been traditionally or historically conceived. So in order to explore these possibilities, contemporary designers have speculated further than previous generations - beyond the task of solving problems by materialising products that do not yet exist. Design has begun to imagine and construct an entirely new function for itself, and one approach has been to explore a view of the world occupied and assembled through fiction.

\section{Fiction within the Design Curricula}

The way in which design navigates, mediates, and translates different epistemologies will be key to its success as interdisciplinary interlocutor. 'The rupture between reality and imagination - the one annexed to fact, the other to theory - has been the source of much havoc in the history of consciousness. It needs to be repaired' (Ingold 2014). Finding a space where this rupture might be addressed - where ideas can be explored and possibilities tested - is an important challenge for a post-disciplinary practice, and it is my contention that the use of fiction within design curricula can be employed to this effect.

'We live', Ballard (1973) writes,

in a world ruled by fictions of every kind - mass merchandising, advertising, politics conducted as a branch of advertising, the pre-empting of any original response to experience by the television screen. We live inside an enormous novel. It is now less and less necessary for the writer to invent the fictional content of his novel. The fiction is already there. The writer's task is to invent the reality.

When adopting a semi-fictional approach to design, the desire to capture a faithful and objective form of reality becomes neither necessary nor desired. Fiction becomes another lens through which to examine and produce the world. Design has employed fiction for decades. Storytelling has always been used to gain tractionto sell an idea to a public or a client. We plot colourful future scenarios that enable a diverse set of 'publics' to engage with, and see themselves benefiting from, the products we want them to buy.

In recent years we have seen an increase in the role of fiction due to our contemporary obsession with 'the future'. Critical and Speculative Design (CSD) has developed a practice that uses fiction as a critical tool to unpack some of the ethical questions posed by current scientific developments, and the technocentric CSD scenarios that populate contemporary design discourse (Dunne and Raby 2001) draw attention to both dystopian and utopian trajectories. Yet however fruitful the telling 
of speculative narratives may be for designers carving out new modes of professional practice, there has been little work investigating the use of fiction as a pedagogic tool within an educational curriculum. As we move towards more unstable markets and changing roles for the designer, fiction becomes a mode of exploration that not only allows students to think through the technologies and social arrangements they imagine but also to question the role and place of design within a professional context.

\section{Fiction as a Transformational and Pedagogic Tool}

The BA (Hons) design programme at Goldsmiths has, in recent years, placed a renewed emphasis on materialism. We recognise that our most valuable insights are the result of a complex interplay between material experimentation and speculative reflection, and staff have developed a curriculum that employs fiction as a 'filter' for material exploration. Within this educational context, we use fiction to generate a playful space for experimentation without 'real world' risks. We encourage students to fabricate worlds that enable them to understand, critique, and engage in the present - unravelling the tangled mess of ideology, narrative, and possibility while also allowing them to reflect upon their learning, diagnose their design process, and map their impact as designers.

In the following section I present four case studies from the programme, and explore how a post-disciplinary design education can enable engagement with the social and political entities of everyday life. Cowboys, Cults and Coney Island (Ward 2011) is the first brief of the second year and sets out to investigate the role of world-building in order to highlight the embedded ideological positions and normative practices of design. Following on from this, The Escape Committee (Loizeau and Ward 2013) asks students to see design as a means of subverting and questioning dominant systems of organisation and control. The third and fourth case studies discuss major projects by final-year students, and demonstrate how fiction can be used to rethink social, economic, and political realities.

\section{Cowboys, Cults and Coney Island}

Cowboys, Cults and Coney Island takes three points of historical and cultural departure: the Cowboys of Kinshasa, the Pana-Wave Cult and Dreamland, and the William H. Reynolds amusement park on Coney Island. 


\section{Cultural Adoption, Transmission, and Re-Territorialisation}

Kinshasa: Tales of the Invisible City (De Boeck and Plissart 2004) traces the influence of cinema as adopted by the disaffected youth of Kinshasa. In this photographic anthropology, De Boeck and Plissart chart the emergence of 'Billism', an adoption of the fashion, language, and social organisation of the Hollywood western within the Republic of Congo's capital. Here, the introduction of an alien material culture into the heart of Africa through the medium of cinema created a form of 'cultural re-territorialisation': 'Billism mobilised and channeled the social forces from the margin' (De Boeck and Plissart 2004: 38) as a mode of resistance against colonial forces. The 'Bills' of Kinshasa allow us to understand that material practices are never 'owned' or stable; akin to Stuart Hall's notion of the 'unfinished conversation' (Akomfrah 2013), material identity is in constant flux. This example highlights the imperative to be sensitive to the production and distribution of cultural entities, seeing them as starting points within material stories - springboards to unfinished cultural practices (Ward and Wilkie 2009).

\section{Embodying Abstract Ideologies}

The Pana-Wave cult of Japan is an example of how extreme forms of doctrine can be reinforced and reproduced through the material culture they create. The Pana-Waves are a UFO religion combining elements of Christianity, Buddhism, and New Wave ideas with the belief that electromagnetic radiation (produced by Communist guerrillas) is destroying their souls. Over the years, they have devised 'quasi-scientific' techniques for deflecting these waves, notably a Scalar Wave Deflector Coil (Chryssides 2012: 269). For the purpose of the brief, the Pana-Waves illustrate the way in which beliefs (however irrational) can be transformed into a material reality to 'make real' the abstract.

\section{Extreme Invention}

The final point of reference is the 'stranger than fiction' phenomenon of Dreamland, the amusement park built on Coney Island in the first decade of the twentieth century. Dreamland included Midget City, 'a re-creation of fifteenth century Nuremberg built to half scale and inhabited by three hundred little people', and the Fall of Pompeii, 'a cyclorama enhanced by mechanical and electrical effects depicting the eruption of Mount Vesuvius and destruction of Pompeii' (Immerso 2002: 68). Here the re-enactment and fictionalisation of collapsed spaces opened up a possibility for entertainment and imagination: 
Reality now supersedes dream, reinforcing the suggestion implicit in Dreamland that the Future is gaining on fantasy, and that Dreamland will be the territory where the actual overtaking occurs. (Koolhaas 1994: 59)

The park included incubators to display premature babies as visitor attractions. Due to the economics of the time, the incubators fast became the best chance of survival for premature infants, and through this twisted reality a form of neonatal innovation occurred. Dreamland demonstrates that technological invention can emerge out of a desire for amusement, and does not necessitate the concerted efforts of university research centres or corporate R\&D groups.

\section{A Framework for Action}

These conceptual drivers mark out the contextual territory, asking students to deconstruct belief systems and understand what lies beneath the material practices of everyday life. The role of this brief within the curriculum is to highlight how design embodies and enforces social and cultural ideas and ideals. It questions how designers navigate the ethically difficult deconstruction or affirmation of these beliefs. The brief also explores the use of fiction in the production of the world around us.

The brief gives a three-stage framework for action. The first stage, The End is Nigh, asks students to identify a cult or special interest group, and then analyse their group's values and ideologies. This subsequently acts as a basis for their world, where the niche becomes the norm and the marginal becomes the mainstream. In order to communicate their ideological analysis, students present the cultural codes and rituals in public, at Speakers' Corner in Hyde Park, London (fig. 1). By forcing them to commit to their group, adopt their ideas (as well as possible prejudices), and evangelise the group's views from a soapbox, the project demands a level of user empathy. The process is akin to method acting, where characters are created, costumes donned, and ideas embraced, effectively putting the students in the position of their users. This could be compared to a form of 'bodystorming' (Burns et al. 1994) or drama therapy: it allows the designer to know (seek knowledge of) his or her users without excessive critical distance.

In the second stage of the brief, Cultural Terraforming, students generate a fictional material culture for their protagonists. They look to form a landscape of activity and objects before trying to consider what their role in the world would be. This process parallels that of the science fiction writer, who invents a universe as a stage for characters to act upon. Through imagining the banalities of everyday existence, we can begin to build rich and compelling characterisation.

We ask students to treat this exercise as a museum might treat a collection of artefacts: as a means to illuminate a strange and foreign country. This process has some similarities with post-processual archaeology, where a subjective narrative of 


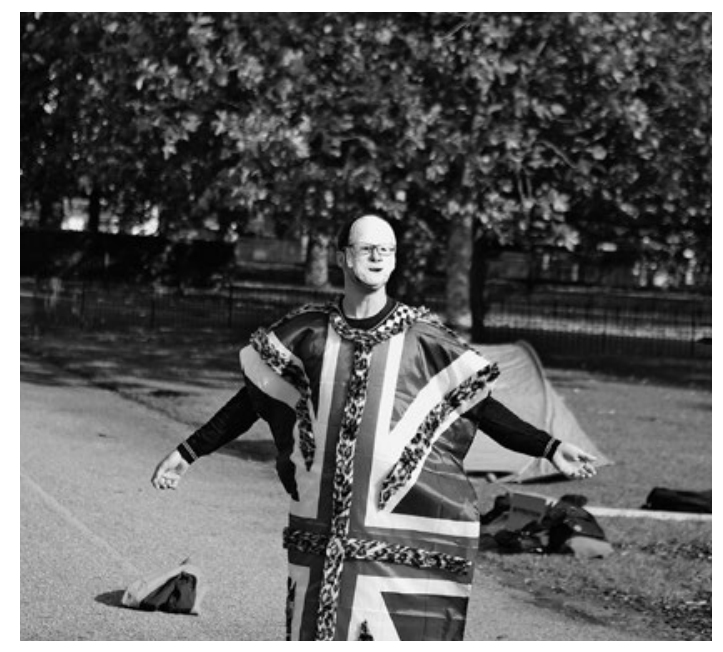

1 The End is Nigh. Student presentations at Speakers' Corner, London (2012)
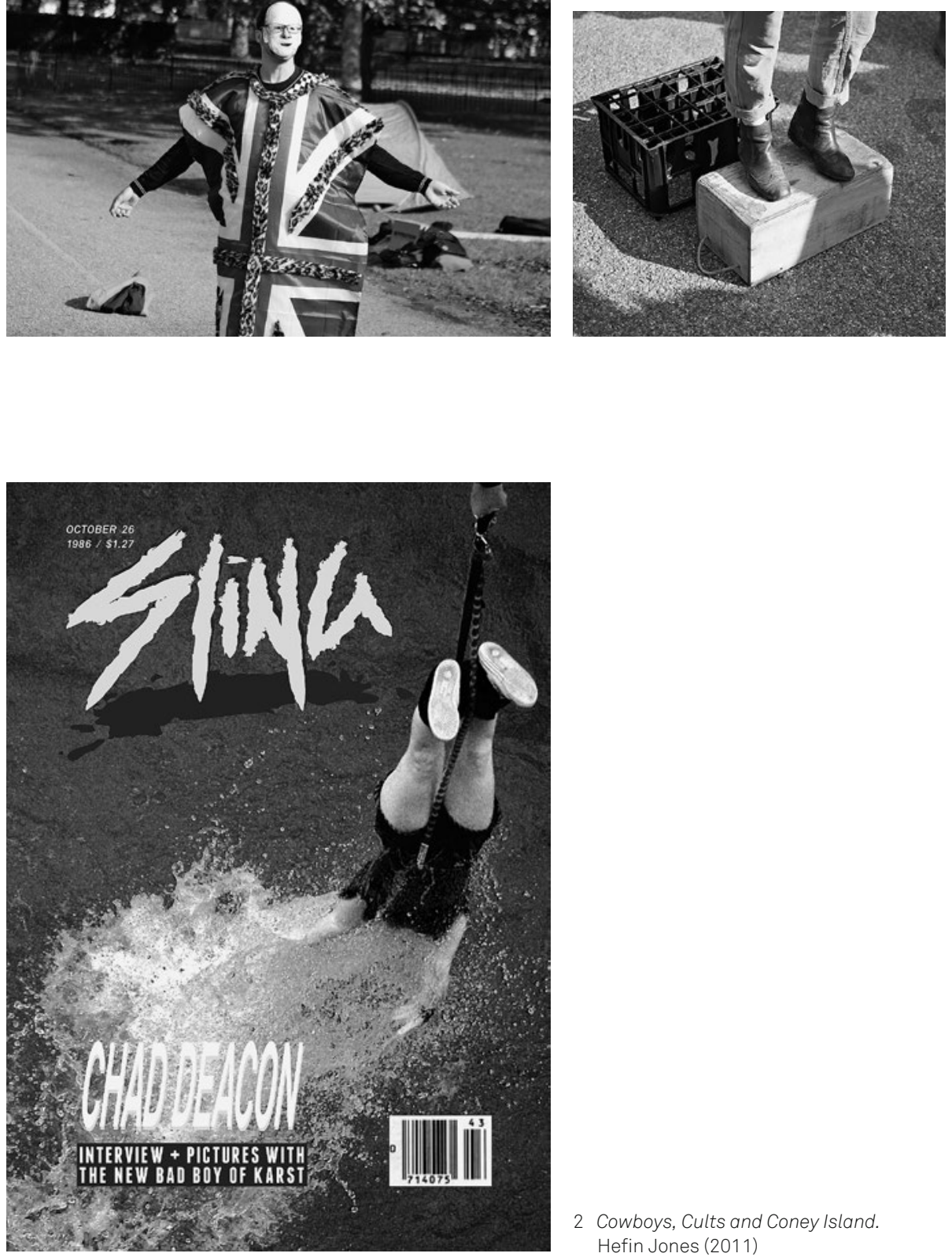

2 Cowboys, Cults and Coney Island. Hefin Jones (2011) 
the social is built from ruins and remnants (Hodder 2003). The students engage in a process of complex cultural referencing and narrative construction, highlighting the need to contextualise their work within the cultural landscape relevant to their site by pulling together and making sense of the rich tapestry of materiality that surrounds all human activity.

Through furnishing their worlds with user narratives, artefacts, spaces, technologies, and media landscapes, they start to build a sensitivity to their (fictionalised) context of production before they take action. In one example, a student selected the London and Thameside Dowsers as his special interest group. During the Terraforming stage, he created a geology to produce conducive subterranean conditions, a geography generated through a dowsing pendulum technique, and a subculture of bungee base jumpers in search of immanent sinkholes, with attendant fanzine and YouTube channel (fig. 2). In this case, the student used the practices of a group to rethink both the environment and material culture, and expanded niche practices into world-building principles.

In the final stage of the brief, Relics from a Near Future, students develop and design a specific part of their new culture, through objects, film, performance, drawing, or visualisation. This is the most conventional element of the brief: designing a 'thing' to fit their world. Our intention here is to highlight that design is essentially a contextual, formative activity and that the examination of context allows for a logic of production, which informs and drives the design decisions throughout the project. In order to evolve this logic, students are encouraged to think rationally about somewhat irrational acts, evaluating their choices and decisions. The aim of this is to demonstrate how a process of rational justification can be applied to almost any situation.

One student selected 'Jedi' or 'Jediism' as his cult. The student began to rationalise a faith based on specific scenes from the Star Wars film franchise, and speculated that if mainstream culture embraced Jediism, a principal act would be the defiance of gravity. He set about creating the architecture and training programme necessary for fighting one of the fundamental forces of the universe. For his final model, the student presented a 'device' that was a cross between a fairground ride and a high-G centrifuge from a space training centre (fig. 3). Rendered as a $3 \mathrm{D}$ model then rapid-prototyped, the object began to legitimise a ridiculous idea. This is something that works across the brief: outcomes can sometimes be dismissed as ridiculous. The idiosyncratic, odd, and marginal are normalised, the students probe society and culture in ways that are not necessarily logical or economically viable, and materialise them as artefacts and architectures.

Educationally and creatively, this type of experimentation is important. Described by Robyn Scott (2014) as 'ridicule risk', there is a sense that truly innovative ideas can only emerge from an atmosphere of trust. Scott proposes a form of 'affirmative action for radical innovation' where crazy ideas are supported both financially and culturally. Applying this to education, we might argue that learning flourishes in a space where the ridiculous is treated with seriousness and sensitivity. 
3 May the forces be with you. Cowboys, Cults and Coney Island. Simon Jeal (2011)

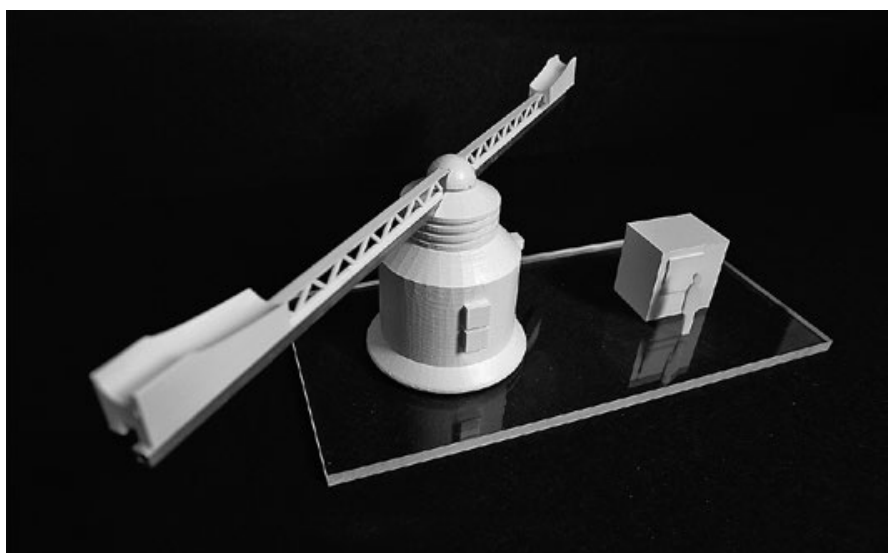

Cowboys, Cults and Coney Island allows the student to move between the rational and the irrational, and allows for creative experimentation - free from the confines of reality.

\section{The Escape Committee}

The second brief, The Escape Committee, works in contrast to Cowboys, Cults and Coney Island. Instead of embodying ideologies in the material realities of design practice, this brief calls for a resistance to dominant forces, using design as a tool to challenge norms - to subvert and transform the everyday. The brief asks students to identify and describe a system they wish to escape from. The primary role of the brief is to question the institutional and infrastructural power relations that form our sociocultural contexts, and highlights the political nature of design practice encouraging engagement as though activist or provocateur.

\section{Reconnaissance and Reality: Finding Boundaries of Acceptability}

The first part of the brief asks students to observe and encounter the structures that shape our social lives. They are challenged to move away from more traditional methods of research, to invent actions that open up creative opportunities or reveal invisible systems. The first task offers several points of departure (Loizeau and Ward 2013):

- Go North.

- Tie someone up (remember health and safety). 
- Get tied up (remember health and safety).

- Become someone else: appropriate/impersonate/roleplay.

- Try to sneak past someone without them knowing (don't get arrested).

- Climb over a wall (don’t get arrested).

- Disappear. Reappear.

- Forge something (not money).

- Leave a conversation before it's over.

- Hide somewhere.

- Catalogue locations, postures, and positions or demeanours.

- Emancipate yourself.

This reads like a hybrid of a Fluxus event score (Friedman, Smith, and Sawchyn 2002) and a Perecian list of everyday engagements (Perec 2008). The task challenges the students to engage with the world in an unusual way: to encounter people, practices, and spaces in a manner distanced from their everyday lives. This form of knowing, playing, and engaging in the world aims to discover the boundaries of acceptability - the borderlands of our social assemblages. To some extent, these methods work like a breaching experiment (Garfinkel 1967) for design practice, uncovering a social convention that restricts action or enforces conformity. In order to find fertile territories for design, we encourage students to relax and play.

During the de-material turn, with its rigorous analysis of design's methods and processes, we have witnessed a move towards a conservatism. Beginning with the Design Methods Group in the 1960s, pioneers such as Horst Rittel and John Chris Jones formalised versions of design that could be easily taught, disseminated, and commercialised. Since then, many educators and curricula have advanced the idea that, as long as you apply the correct method, fruitful innovation will follow. One such method that has been widely adopted by designers is ethnography.

In recent years, ethnography has been widely adopted by practitioners and educators as the de rigueur method for shedding light on social realities. However, when applied without appropriate care, attention, and imagination, it can lead to instrumental and predictable results. 'Towards Fantastic Ethnography and Speculative Design' (Galloway 2013) highlights the fertile possibilities of mixing fiction and ethnography. Galloway draws on Ursula Le Guin to remind us to 'probe what exists beyond realism' (Galloway 2013), and this inventive approach is essential within design education. Our role as educators is to introduce as many methods and processes as possible, giving students the confidence to assemble their own unique practice. This aims to avoid a formulaic approach, and promotes a deeply personal learning experience.

During the research phase, it is important for tutors and students to remain open to unexpected project directions. One student chose to observe and analyse London's roundabouts (traffic islands) as strange and alien non-spaces (fig. 4). In 
4 Dead Space. The Escape Committee. Rhianna Bowen (2014)

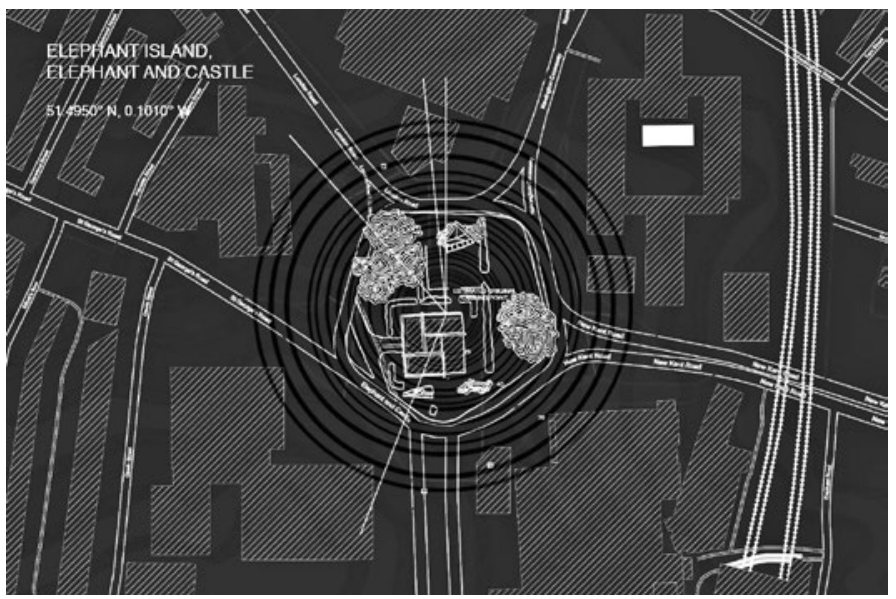

order to distance herself from the banality of the space, she created a short documentary presenting urban space as an extraterrestrial archipelago:

Elephant Island: I have explored these islands. Elephant Island is a strange and futuristic environment. The central point is a large, square building, made up of mirrored, concave squares. While this appears fantastical, it is marred by acid-yellow signs proclaiming 'DANGER OF DEATH'. Huge metal pipes protrude from the roof like the legs of a spider. Elephant Island is a somewhat hostile environment; it is divided into sections, and there is an air of the forbidden: a forgotten future. This narrative is evidenced by the story behind the island; it is said that the Martians who created the structure left Earth quickly; the atmosphere too hostile to ensure their survival. (Excerpt of project description, 2014)

This diversion into a form of fictional urban geography was neither the intention nor the direction of the brief, yet what emerged was fascinating. Rereading the city as fictional text is reminiscent of Calvino (1997), Raban (1998), and Keiller (1994) and opens up an imaginative trajectory for future projects.

\section{Planning and Scheming: A Blueprint of Contingent Action}

The second part of the brief asks the students to make a plan of action, to design the mode and means of their escape. Here we engage students in the scripting of an event, to understand and manage the contingent possibilities of action, thus challenging them with the awkward tension between the intention of the designer and an unpredictable social realm. 
In Architecture Depends, Jeremy Till charts architecture's failure to adapt to an increasingly contingent formative context: a retreat into idealism, away from the 'colossal forces' of the modern world (2009: 45). He argues for an approach that embraces the opportunities found in contingency: 'Where order and certainty close things down into fixed ways of doing, contingency and uncertainty open up liberating possibilities for action' (2009: 55). The Escape brief challenges students to understand the contingency of the context in which their work will be received, in order to build the skills necessary for responsiveness and agility as designers.

In 'The De-Scription of Technical Objects', Madeline Akrich conceptualises the scripts designed into objects and their role in directing the social (1997: 208): 'Thus, like a film script, technical objects define a framework of action together with the actors and the space in which they are supposed to act.' If we consider that all socio-technical systems in some way script action, the key questions are:

1. To what extent do the scripts written into objects and systems affect the behaviour of their users?

2. What is the role of the designer in writing (and un-writing) these scripts?

As we move towards a post-disciplinary practice, we need to develop new approaches to the writing, editing, and performing of these scripts, where these become maps of contingent action - open or partial scripts - that are easily adapted and edited. Sometimes the intentions of designers and commissioners are socially and politically driven. However, as with all political intentions, there are alternative positions. The means by which these scripts can be subverted and rewritten opens up a rich territory for design and learning.

\section{A Dress Rehearsal for Reality}

Once a plan is formulated, we ask the students to enact a dress rehearsal. By performing their intentions, they start to refine and revise their original plan. This is part prototyping process, part role play: testing their characters, script, and interaction with a model of reality.

Designers often suffer from oversimplifying user behaviour. Assumptions are often built on prejudices, generalisations, and cultural assumptions. As Akrich observed: 'It may be that no actors will come forward to play the roles envisaged by the designer. Or users may define quite different roles of their own. If this happens, the objects remain a chimera, for it is in the confrontation between technical objects and their users that the latter are rendered real or unreal' (1997: 208). For this reason, students need to prototype a series of viable interactions, opening up opportu- 
nities for adaptation and iteration. This is reminiscent of Latour's 'slight surprise of action' (1999: 266) where we only understand possibility through action.

The Escape Committee challenges students to understand the world as a complex network of actors, where the designer's intention is not always achievable and user behaviour remains unpredictable. It challenges them to critique dominant discourses and societal frameworks to understand their role in the world, while developing a process of engagement where consequences are neither certain nor dogmatic, but negotiated and contingent.

\section{Social Empowerment through Participatory Speculation}

The final case studies are examples of projects completed by third-year students. With the guidance of a tutor, students set up a territory for investigation and produce work to interrogate key questions located within this space. Two finalists Tearlach Byford (2014) and Hefin Jones (2013) - engaged with vastly different subjects (mining and space travel, respectively), but each used fiction as a device to prototype new forms of social and political engagement.

\section{The Architecture of Legitimacy}

In 2013, Byford began by investigating mining as a historical and material phenomenon. He was interested in how the social, economic, and representational reality of mining had changed in the UK over the last century. He developed a project that hybridised ecological lobbying, paternal capitalism, and labour organisation. The Social Mining Union (SMU) reconceptualised the trade union for contemporary scrap collectors in the twenty-first century and combined social engagement with political lobbying power through the acquirement of shares in Glencore plc (Byford 2014a). The outcomes of the project included: an organisational structure, a financial system, a set of tools for mining scrap, an identity for the union, and a fictional identity for himself, the union leader (fig. 5). The project culminated with a visit to Glencore's annual general meeting in Switzerland, to confront the board with questions about their corporate social responsibility.

In an interview with Byford six months after he completed the project, I asked him how he used fiction throughout his project. Reflecting on the way in which he built his narrative, Byford observed: 'Part of my fictionalizing was creating a character for myself. I designed a business card, a personality, a suit: it was the architecture of legitimacy' (2014b). Through building and writing fiction, he found realworld legitimacy. By trying to understand the role he would inhabit during his (eventual) engagement with the organisation, he materialised props that could 


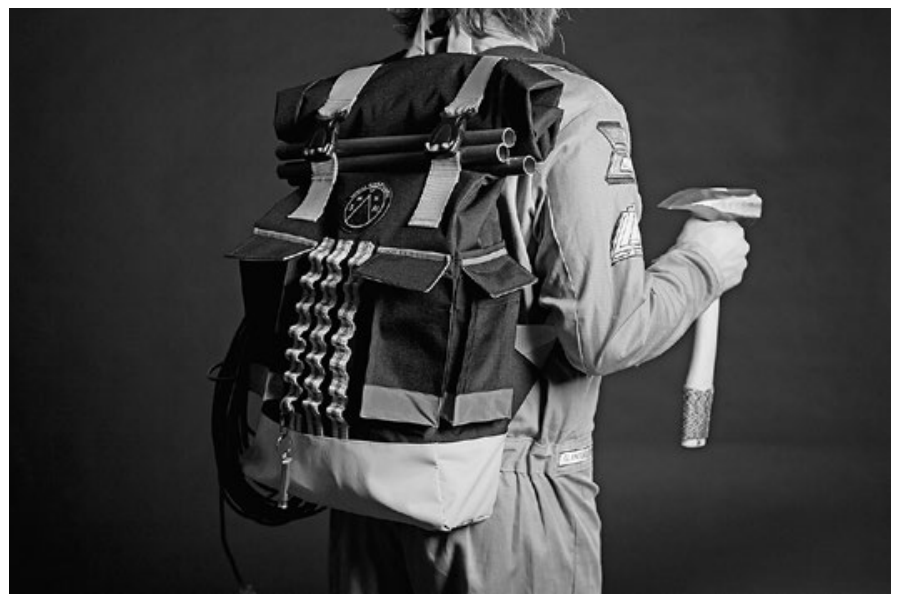

shape and validate his character. His alternate identity grew from a network of material statements - an identity in the real world assembled by virtue of a semi-fictional design practice.

This method differs from the typical mechanisms of political engagement and the traditional roles of design practice. In this example, the designer constructs a political event through the material entities that constitute the formative context. Engagement evolves through a material support structure, and distributive agency is performed in the spaces in between the human and non-human actors. Tools, stage direction, and behaviours are prototyped through fiction but enacted in a real forum, where they come into being with a slight 'surprise of action'.

Within emergent design discourse centred on the notion of 'Design Fiction' (Dunne and Raby 2001 and 2013; Bleecker 2009; Sterling 2009), the interplay between fiction and reality remains relatively simplistic and sometimes dangerously privileged (Prado de O. Martins 2014). The fiction functions as a way either to reflect upon, question, or critique the present or to inspire new ideas in the present through a form of 'diegetic prototyping' (Kirby 2009). However, the relationship is far more complex. A porous boundary is created, where fiction starts to mould and influence the real, pulsing at micro- and macro-scales of influence: 'That's the thing with design [...] when something is materialised, it becomes real. I designed the badge, it wasn't real until I was sent two hundred of them. The identity of the Union became a real thing, through the act of making' (Byford 2014b). It is in this confluence of fiction and 'vital materialism' (Bennett 2010) that opportunities are unlocked for the post-disciplinary designer, and the dominant paradigm shifts from 'designer as problem-solver' towards 'citizen sense-maker' (Till 2009: 168). 
6 Welsh Space Campaign.

Final-year project.

Hefin Jones (2013).

(Photo: Geraint Morgan)

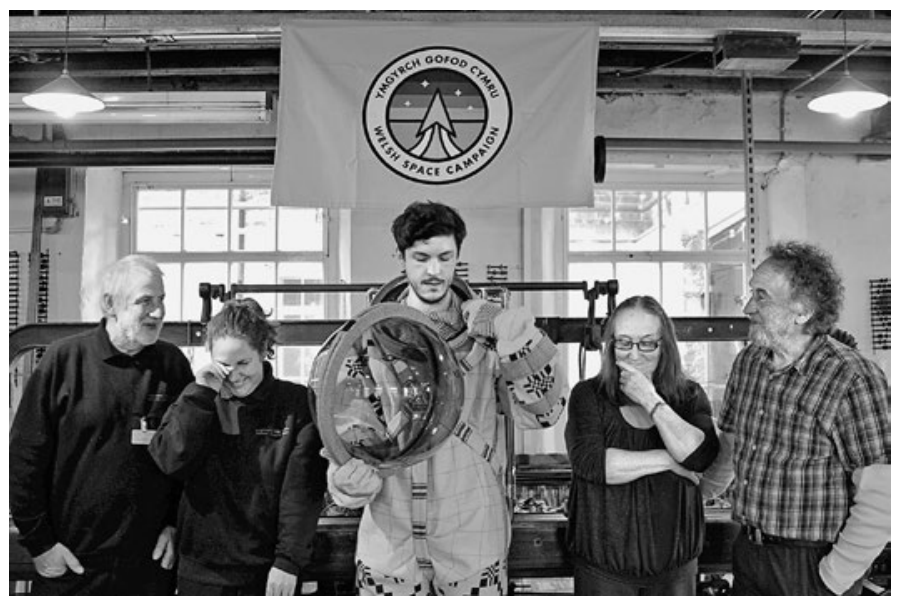

The Ethics of Participatory Speculation

The second case study comes from Hefin Jones, whose final project, the Welsh Space Campaign (WSC), was first shown in June 2013 but has subsequently been developed and exhibited farther afield (Crafting Narrative 2014, The Future of Fashion is Now 2014). Jones started his project with a question: could a Welshman travel to outer space? From this simple beginning (a musing scribbled on a Post-it note), he designed a process of participatory engagement to allow local trade and crafts communities to engage in a cosmic imaginary. He set about designing and making a spacesuit using traditional (declining) Welsh crafts, and what began as a flight of the imagination emerged as a celebration of Welsh craft heritage (fig. 6). By engaging people in the possibility of interstellar travel, Jones created a mechanism for participatory speculation.

Like Byford, Jones engaged in a different form of fiction-making. He eventually saw his project as an opportunity for community engagement and a way to reinvigorate dying industries, but initially he had a different aim: 'I wanted to make it believable. This was one of the first ideas for the WSC: how can I trick my town [into believing] that I've been to outer space?' (Jones 2014). The desire to 'make believe', to create a vision of a future that allows an audience to suspend their disbelief, is a common trope of CSD. However, we need to question the ethical implications of this tendency towards visual and conceptual trickery. The relationship between designer and audience (user) changes when a level of speculation and participation is introduced - when design no longer offers solutions to the acknowledged problems but instead questions their agency in the material world. The skills and sensitivities needed to guide people through complex networks of opportunity and possibility are only just beginning to be understood. 
Jones is now working in a UK not-for-profit design-led social enterprise, where participatory work is key to innovation within the public sector. I asked how his understanding of participation had changed since graduation: 'There's a realization that participation is a very isolated event in the process of a project. I'm interested in questioning this; how do we make user engagement meaningful beyond a workshop or singular event?' (Jones 2014). This highlights a key concern for the post-disciplinary designer: how do we engage and steer stakeholders without seeing them as a 'resource' or abandoning them once the funding runs out or the project ends? The WSC exemplifies a new conceptualisation of both speculation and participation, which begins to form a model of practice where the designer has a role akin to stewardship, where they 'must be involved over the duration of change processes, providing constant expertise and feedback to identify, test, and deliver durable solutions' (Helsinki Design Lab, n.d.).

\section{Conclusion: Training for the Revolution}

In summary, I have sketched out an alternative approach to design education to meet the demands of a changing world, where distributive agency or vibrant matter offers an alternative role for design. No longer can we retreat behind the walls of disciplinary specialisms or abstract our practice to a series of Post-it notes. We are compelled, by our rapidly changing social, economic, and environmental context, to seize the transformational power of post-disciplinary practice. We need to devise new methods and processes for the manipulation and mastery of our 'new material', enabling us to prototype the changing political terrain.

Through the case studies, I demonstrated how the function of fiction within the curriculum could build a safe space for exploration and experimentation, free from the risk of ridicule. It is through fiction as a pedagogic tool that we see the interplay between the imagined and the real. In order to parry the attack of 'the real world', we need to defend our fictional irrational worlds, building a logic of production that demonstrates value and potency. The attack of the real need not be an excuse for a lack of inventiveness in the methods that we deploy; to remain open to the opportunities of a redirected practice, we need to be light on our feet and not too precious with our methods. It is through the identification of new objects of design (action scripts, policy documents, organisational structures) that we will shift our practice and place within industry.

In order to embrace the opportunities found within our contingent contexts, we need to be cognisant of the ethical implications of speculative participation and be attentive to the new responsibilities of the designer in the twenty-first century. If we fail to rethink our approach to design education, we risk condemning our practice to the subservience of market-driven consumption. In order to capitalise on the 


\title{
position of design, we need to teach our students to be agile, to understand design as a 'process of continual improvisation' (Bennett and Joyce 2013: 8).
}

\author{
References and Bibliography
}

Akomfrah, J. (director) (2013). The Unfinished Conversation [film]. London: BFI.

Akrich, M. (1997). 'The De-Scription of Technical Objects'. In Bijker, W.E., and Law, J. (1997).

Shaping Technology/Building Society: Studies in Technological Change. Cambridge, MA: MIT Press.

Ballard, J.G. (1973). Crash. Introduction to the French edition (1974) of Crash (1973). Reprinted in Re/Search no. $8 / 9$ (1984)

Bennett, J. (2010). Vibrant Matter: A Political Ecology of Things. London: Duke University Press.

Bennett, T., and Joyce, P. (2013). Material Powers: Cultural Studies, History and the Material Turn. Abingdon, Oxon: Routledge.

Bleecker, J. (2009). Design Fiction: A Short Essay on Design, Science, Fact and Fiction. Near Future Laboratory, March 2009. Retrieved 7 January 2015 from: http://blog.nearfuturelaboratory.com/2009/03/17/designfiction-a-short-essay-on-design-science-fact-and-fiction/.

Boyer, B., Cook, J.W. and Steinberg, M. (2013). Legible Practises: Six Stories About the Craft of Stewardship. Helsinki: Sitra.

Brown, T. (2008). ‘Design Thinking’. In Harvard Business Review. Retrieved 15 December 2014 from:

https://hbr.org/2008/06/design-thinking.

Bryant, L., Srnicek, N., and Harman, G. (eds.) (2011). The Speculative Turn: Continental Materialism and Realism. Melbourne: re.press.

Burns, C., Dishman, E., Verplank, W., and Lassiter, B. (1994). 'Actors, Hairdos \& Videotape: Informance Design'. In Proceedings of CHI 94, Boston, MA, pp. 119-20.

Byford, T. (2014a). 'The Social Mining Union' [project website]. Retrieved 15 December 2014 from:

http://tearlach.co.uk/index.php/project/the-social-mining-union/.

Byford, T. (2014b). Interviewed by Matthew Ward, Goldsmiths, University of London, 4 November 2014.

Calvino, I. (1997). Invisible Cities. Translated by William Weaver. London: Vintage.

Chryssides, G.D. (2012). Historical Dictionary of New Religious Movements. Lanham, MD: Rowman \&

Littlefield.

Coldstream Report (1970). 'The Structure of Art and Design Education in the Further Education Sector'. Report of a Joint Committee of the National Advisory Council on Art Education and the National Council for Diplomas in Art and Design. London: HMSO.

Crafts Council (2014). 'Our Future is in the Making: An Education Manifesto for Craft and Making'. Retrieved 15 December 2014 from: http://www.craftscouncil.org.uk/content/files/7822_Education_manifesto@14FINAL.PDF.

Cross, N. (2001). 'Designerly Ways of Knowing: Design Discipline versus Design Science'. In Design Issues 17, no. 3, pp. 49-55.

Danish Designers Manifesto (2010). 'The Role of Design in the 21st Century'. Retrieved 19 December 2014 from: http://www.humancentereddesign.org/sites/default/files/Manifesto-UK.pdf.

De Boeck, F., and Plissart, M.-F. (2004). Kinshasa: Tales of the Invisible City. Leuven, Belgium: Leuven University Press.

Dezeen (November 2014). 'Design Education is Tragic'. Retrieved 15 December 2014 from: http://www.dezeen.com/2014/11/13/design-education-tragic-says-jonathan-ive-apple/.

Dunne, A., and Raby, F. (2001). Design Noir: The Secret Life of Electronic Objects. Berlin: Springer.

Dunne, A., and Raby, F. (2013). Speculative Everything: Design, Fiction, and Social Dreaming. Cambridge, MA and London: MIT Press.

Friedman, K., Smith, O., and Sawchyn, L. (eds.) (2002). The Fluxus Performance Workbook. Performance Research e-Publications.

Galloway, A. (2013). 'Towards Fantastic Ethnography and Speculative Design'. Ethnography Matters (blog). Retrieved 15 December 2014 from: http://ethnographymatters.net/blog/2013/09/17/towards-fantasticethnography-and-speculative-design.

Garfinkel, H. (1967). Studies in Ethnomethodology. Englewood Clifs, NJ: Prentice-Hall. 
Goffman, E. (1990). The Presentation of Self in Everyday Life. London: Penguin.

Helsinki Design Lab (n.d.). 'What is Strategic Design?' Retrieved 15 December 2014 from:

http://www.helsinkidesignlab.org/pages/what-is-strategic-design.

Hicks, D. (2010). 'The Material-Cultural Turn: Event and Effect'. In Hicks, Dan, and Beaudry, Mary C. (eds.). The Oxford Handbook of Material Culture Studies. Oxford: Oxford University Press, pp. 25-98.

Hill, D. (2012). Dark Matter and Trojan Horses: A Strategic Design Vocabulary. Moscow: Strelka Press.

Hodder, I. (2003). Archaeology beyond Dialogue. Salt Lake City: University of Utah Press.

Immerso, M. (2002). Coney Island: The People's Playground. New Brunswick, NJ: Rutgers University Press.

Ingold, T. (2014). 'That's Enough about Ethnography!' In Hau: Journal of Ethnographic Theory 4, no. 1,

pp. 383-95.

Inns, T. (2010). Designing for the 21st Century: Interdisciplinary Methods and Findings. Farnham, Surrey:

Gower.

Jones, H. (2014). Interviewed by Matthew Ward, Goldsmiths, University of London, 17 November 2014.

Keiller, P. (director) (1994). London [film]. London: BFI and Channel 4.

Kimbell, L. (2009). 'Beyond Design Thinking: Design-as-Practice and Designs-in-Practice'. Paper presented at CRESC Conference, Manchester, UK, September 2009.

Kimbell, L. (2011). 'Rethinking Design Thinking: Part I'. In Design and Culture 3, no. 3, pp. 285-306.

Kirby, D. (2009). 'The Future is Now: Diegetic Prototypes and the Role of Popular Films in Generating

Real-World Technological Development'. In Social Studies of Science 40, no. 1 (2010), pp. 41-70.

First published 30 September 2009.

Koolhaas, R. (1994). Delirious New York: A Retroactive Manifesto for Manhattan. London: Monacelli Press.

Latour, B. (1999). Pandora's Hope: Essays on the Reality of Science Studies. Cambridge, MA: Harvard Uni-

versity Press.

Loizeau, J., and Ward, M. (2013). The Escape Committee: The Getaway. Project Brief, BA (Hons) Design,

Goldsmiths, University of London.

Perec, G. (2008). Species of Spaces and Other Pieces. Harmondsworth, Middlesex: Penguin.

Pigott, R. (2003). 'Rise of Japanese Cults'. Retrieved 15 December 2014 from: http://news.bbc.co.uk/1/hi/ world/asia-pacific/3029183.stm.

Prado de O. Martins, L. (2014). 'Privilege and Oppression: Towards a Feminist Speculative Design'. In Lim,

Y.K., Niedderer, K., Redström, J., Stolterman, E., and Valtonen, A. (eds.). Proceedings of DRS 2014: Design's

Big Debates. Umeå, Sweden: Umeå Institute of Design, Umeå University.

Press, M., and Cooper, R. (2003). The Design Experience: The Role of Design and Designers in the Twenty-First Century. Farnham, Surrey: Ashgate.

Raban, J. (1998). Soft City. London: Harvill Press.

Scott, R. (2014). 'Risk and Reward: Four Thought, Series 4' [radio programme]. London: British Broadcasting Corporation. Broadcast on Radio 4, 22 October 2014.

Snow, C.P. (1959). The Two Cultures. The Rede Lecture. Cambridge: Cambridge University Press. Retrieved 15 December 2014 from: http://s-f-walker.org.uk/pubsebooks/2cultures/Rede-lecture-2-cultures.pdf.

Souleles, N. (2013). 'The Evolution of Art and Design Pedagogies in England: Influences of the Past,

Challenges for the Future'. In International Journal of Art \& Design Education 32, pp. 243-55.

Sterling, B. (2009). 'Design Fiction'. In Interactions 16, no. 3, pp. 20-24.

Till, J. (2009). Architecture Depends. Cambridge, MA and London: MIT Press.

Ward, M. (2011). 'Cowboys, Cults and Coney Island: Design for Alternative Possibilities'. Project Brief, BA (Hons) Design, Goldsmiths, University of London.

Ward, M., and Wilkie, A. (2009). 'Made in Criticalland: Designing Matters of Concern'. In Networks of Design.

Proceedings of the 2008 Annual International Conference of the Design History Society (UK), University

College Falmouth, 3-6 September. Available at: UniversalPublishers.com. 